\title{
Detection of harmful foodborne pathogens in food samples at the points of sale by MALDT-TOF MS in Egypt
}

\author{
Dalia F. Khater ${ }^{1}$, Radwa A. Lela ${ }^{1}$, Mohamed El-Diasty ${ }^{2}$, Shawky A. Moustafa ${ }^{3}$ and Gamal Wareth $34^{3}$ (D)
}

\begin{abstract}
Objectives: Microbes can contaminate foodstuffs resulting in foodborne illnesses. Investigating microbial hazards in foods at the point of sale with rapid tools is required to avoid foodborne illness outbreaks. The current study aimed to identify the microbial hazards in food samples collected from retail shops at sale points using MALDI-TOF MS.

Results: Food samples were collected from stores and supermarkets in four Delta cities (Tanta, Kutour, Kafr-Elzayat and Benha). Analysis of 178 samples of fish, meat and dairy products revealed 20 different bacterial species. $44.76 \%$ of isolates were identified as E. coli, 17.44\% were identified as Enterobacter spp., and E. cloacae was predominant. 12.2\% were identified as Citrobacter spp., and C. braakii was predominant, and 8.7\% were identified as Klebsiella spp., and K. pneumoniae was predominant. Moreover, eight Proteus mirabilis, six Morganella morganii, five Staphylococcus hominis, three Serratia marcescens, two Pseudomonas aeruginosa, one Salmonella typhimurium and one Enterococcus faecalis were detected. Foodstuffs not only be contaminated during production and processing but also during storage and transport. Identification of harmful human pathogens in foodstuffs is alarming and consider threatening to public health. Identification of microbiological hazards in foods using MALDI-TOF MS provides an efficient tool for identifying foodborne pathogens.
\end{abstract}

Keywords: Food Monitoring, Bacterial Hazards, Foodborne, Detection, MALDT-TOF MS, Egypt

\section{Introduction}

Protection of humans from foodborne diseases is challenging. Several countries have well-developed infrastructures for monitoring food quality. However, still safe and healthy food regarding bacterial contamination a significant challenge [1]. Many microbes can contaminate foodstuffs resulting in severe health and economic implications [2]. Some are coming from the source, and some contaminate during manufacturing. Several foodborne outbreaks attributed to microbiological hazards have occurred worldwide and are associated with

\footnotetext{
${ }^{*}$ Correspondence: gamal.wareth@fli.de

${ }^{3}$ Faculty of Veterinary Medicine, Benha University, Moshtohor,

Toukh 13736, Egypt

Full list of author information is available at the end of the article
}

mortalities and economic burdens [3-5]. Thus, rapid detection of pathogenic bacteria in foodstuffs ready for human consumption is of great importance to prevent foodborne disease outbreaks and ensure food safety [6]. In Egypt, the hazard of bacterial occurrence in the food chain exists [7-9]. Methicillin-resistant Staphylococcus aureus (MRSA) was isolated from humans, animals and milk samples [10] and implicated in several food poisoning outbreaks $[9,11]$. Several foodborne illness outbreaks associated with consuming raw or insufficiently processed foods were reported $[7,8,11]$. The highly pathogenic E. coli $\mathrm{O} 157$ and other Enterobacteriaceae members were recovered with a high prevalence from dairy and meat products [12] and were responsible for severe illness among patients in different governorates [13]. Multidrug resistance (MDR) Pseudomonas aeruginosa strains

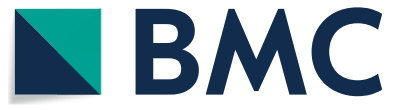

(C) The Author(s) 2021. This article is licensed under a Creative Commons Attribution 4.0 International License, which permits use, sharing, adaptation, distribution and reproduction in any medium or format, as long as you give appropriate credit to the original author(s) and the source, provide a link to the Creative Commons licence, and indicate if changes were made. The images or other third party material in this article are included in the article's Creative Commons licence, unless indicated otherwise in a credit line to the material. If material is not included in the article's Creative Commons licence and your intended use is not permitted by statutory regulation or exceeds the permitted use, you will need to obtain permission directly from the copyright holder. To view a copy of this licence, visit http://creativeco mmons.org/licenses/by/4.0/. The Creative Commons Public Domain Dedication waiver (http://creativecommons.org/publicdomain/ zero/1.0/) applies to the data made available in this article, unless otherwise stated in a credit line to the data. 
harbored resistance genes were isolated from fish farms [14]. Typhoid fever is an endemic disease in Egypt, and the infection is mainly associated with contamination of foods with Salmonella enterica [15]. The burden of microbiological hazards in food appeared clearly in summer 2018 after two British couple's death because of $E$. coli and Shigella's, which are most prevalent in animals and associated with disease occurrence [16].

Several diagnostic tools are used for the detection of foodborne pathogens. Molecular detection of Aeromonas hydrophila in fish was carried out by Restriction Fragment Length Polymorphism (RFLP) [17]. PCR was applied in MRSA diagnosis [9] and detection of resistance genes [18]. Loop-mediated isothermal amplification (LAMP) was developed to detect foodborne pathogens by amplifying certain genes [19]. The current pathogen detection methods in foodstuff, either by culturing and biochemical tests or using different DNA-based assays are time consumers. They require biological culture, DNA extraction and amplification, or sequencing. However, Matrix-Assisted Laser Desorption/Ionization Timeof-Flight Mass Spectrometry (MALDI-TOF-MS) can identify the pathogen from a single colony into species level in a short time. The current study aimed to investigate the potential microbiological hazards in various food samples ready to sale for human consumption in the Delta region of Egypt and application of mass spectrometry as a useful tool for investigating foodborne pathogens.

\section{Main text}

\section{Materials and methods}

178 milk, meat, and fish products were collected from food stores and supermarkets in four Delta region cities during summer 2017. Ninety-two samples were collected from Tanta, the capital city of Gharbia governorate. Forty-two and thirty-six samples were collected from Kutour and Kafr-Elzayat cities of the same governorate, respectively. Eight samples were collected from Benha, the capital city of Qalyobia governorate. The samples included 108 milk products (fresh milk, cheese, yogurt, and ice cream), 47 minced meat and chicken, and 23 specimens of fish products (fillet meat and catfish) (Table 1). All food specimens were collected at points of sale. Samples were collected and transferred in sterile plastic bags within ice boxes to the Department of Food Hygiene at Animal Health Research Institute within one hour. Samples were enriched in nutrient broth. A sterile cotton swab was dipped into the broth and streaked on Columbia Agar, Columbia Nalidixic Agar (CNA), MacConkey and Mannitol Salt Agar (Oxoid Limited, Thermo Fisher Scientific, Germany). The plates were incubated at $37^{\circ} \mathrm{C}$ for $24-48 \mathrm{~h}$. Colonies with different morphological characteristics were harvested and subcultured on blood
Table 1 Type and number of food specimens collected from retail shops at the point of sale in four cities of Egypt's Delta region

\begin{tabular}{lc}
\hline Type of samples & No. of samples \\
\hline Dairy products $(\mathrm{n}=108)$ & 59 \\
Fresh milk & 25 \\
Cottage cheese & 15 \\
Fresh cheese & 7 \\
Yogurt & 2 \\
Ice cream & \\
Meat products $(\mathrm{n}=47)$ & 42 \\
Minced meat & 5 \\
Chicken meat & \\
Fish products $(\mathrm{n}=23)$ & 15 \\
Fillet fish meat & 8 \\
Catfish & 178 \\
Total &
\end{tabular}

agar for further purification. Pure colonies of bacteria were collected by Amies agar gel with charcoal transport swabs (Thermo-Fisher Scientific, Germany) and sent directly for species identification using the MALDI-TOF MS assay.

Bacterial swabs were culture on blood agar media with $7,5 \%$ blood and incubated at $37^{\circ}$ with $5 \% \mathrm{CO}_{2}$ for 24-48 h. In a $1.5 \mathrm{ml}$ Eppendorf tube, a single fresh colony from each plate was suspended in $300 \mu \mathrm{l}$ of HPLC grade water and completely homogenized using a vortex. The bacteria were inactivated by $900 \mu \mathrm{L}$ of absolute ethanol to each tube and then vortex again. Protein extraction from each sample was done as described before [20]. Inactivated bacterial pellets were collected by centrifugation for $2 \mathrm{~min}$ at $11,000 \mathrm{~g}$. The pellets were air-dried to remove ethanol traces and then were reconstituted in $50 \mu \mathrm{L}$ of $70 \%$ formic acid and $50 \mu \mathrm{L}$ of acetonitrile. The samples were sonicated $(100 \%$ amplitude and 1.0 duty cycle) for $1 \mathrm{~min}$ on ice and were centrifuged at 11,290g for $5 \mathrm{~min}$ at room temperature, and the clear supernatant was collected. One $\mu \mathrm{L}$ of each supernatant was spotted onto the MALDI target (MSP 96 target polished steel (MicroScout Target) plate; Bruker Daltonik, Bremen, Germany), air-dried and overlaid with $1.0 \mu \mathrm{L}$ of saturated $\alpha$-cyano-4-hydroxycinnamic acid matrix solution (in $50 \%$ acetonitrile and $0.25 \%$ trifluoroacetic acid). The MALDI measurements were carried out using a Microflex LT (Bruker Daltonics, Bremen, Germany) instrument and MBT Compass Explorer 4.1 software. The MALDI Biotyper manufacturer's recommendation on the log score value of $0-3$ for species identification was followed. Only bacterial species with score values equal to or more than 2.300 were considered reliably identified bacteria by 
MALDI-TOF MS. Isolates identified with score values less than 2.300 were excluded from the analysis.

\section{Results and discussion}

MADLT-TOF MS successfully identified 172 bacterial isolates belonging to 20 different species. The identified bacteria included Enterobacteriaceae e.g. E. coli, Salmonella typhimurium, Klebsiella spp., Proteus mirabilis, Enterobacter spp., Serratia marcescens, Citrobacter spp., and other disease-causing bacteria (Table 2). E. coli was the most prevalent and represented $44.76 \%(n=77)$ of isolates. E. coli was isolated from minced meat, chicken, fillet fish, fresh milk, yogurt, cottage and fresh cheese. C. braakii, E. cloacae and K. pneumoniae were representing $8.1 \%, 7 \%$ and $6.4 \%$, respectively. Examination of bacterial hazards in milk samples collected from bovine revealed high incidence of $E$. cloacae, K. pneumoniae, $K$. oxytoca, E. coli, and C. freundii [21]. Examination of sixty cheese samples from retailing markets in Cairo, Giza, and Monufia revealed contamination with E. coli and $P$. aeruginosa in $26.6 \%$ and $1.66 \%$ of samples, respectively [22]. One strain of S. Typhimurium was isolated from fillet fish meat. S. Typhimurium is a common pathogen present in broilers flocks in Egypt [23], and contaminate chicken meat either in farm or during processing [24]. However, isolation of S. Typhimurium from fillet fish meat is uncommon in Egypt. 25\% (43/172) of identified species were belonging to ESKAPE pathogens. ESKAPE is a group of bacterial pathogens commonly associated with MDR and encompasses E. faecium, S. aureus, $K$. pneumoniae, A. baumannii, P. aeruginosa and Enterobacter spp [25]. Thirty Enterobacter spp. (17.4\%) were isolated from meat, fish and dairy products, and E. cloacae was predominant in 12 samples. Fifteen Klebsiella spp. were identified, and eleven (6.4\%) were confirmed as $K$. pneumoniae. Of them, five were isolated from catfish meat, five from fresh milk samples and one from ice cream. K. pneumoniae is a major human pathogen that is highly common in Egyptian hospitals [26] and the environment [27]. Carbapenemase-producing K. pneumoniae were recovered at high frequency among broilers, drinking water and workers at poultry farms [28]. Examination of twenty brackish-water fish farms located in Damietta and Kafr-elshekh governorates revealed K. pneumoniae, E. cloacae and E. coli in $6.6 \%, 4.7 \%$ and $4.0 \%$ of samples, respectively [29]. Two $P$. aeruginosa were identified in milk samples obtained from Kutour city. P. aeruginosa was detected with a high level in camel meat [30], cheese

Table 2 Bacterial species, geographical distribution and number of strains identified by MALDI-TOF MS in food specimens collected from retail shops at point of sale in Delta region

\begin{tabular}{|c|c|c|c|c|c|}
\hline No & Genus and its prevalence (\%) & Bacterial species & Type of food specimens & City & No. of isolates \\
\hline 1 & Escherichia coli (44.76\%) & E. coli & $\begin{array}{l}\text { Minced and chicken meat, fillet fish meat, } \\
\text { milk, yogurt, cottage, and fresh cheese }\end{array}$ & Tanta, Kutour, Kafr-Elzayat, Benha & 77 \\
\hline \multirow[t]{4}{*}{2} & Enterobacter spp. (17.44\%) & E. cloacae & $\begin{array}{l}\text { Minced meat, fillet fish meat, cottage } \\
\text { cheese, milk }\end{array}$ & Tanta, Kutour, Kafr-Elzayat, & 12 \\
\hline & & E. asburiae & $\begin{array}{l}\text { Fillet fish meat, minced meat, ice cream, } \\
\text { cottage cheese }\end{array}$ & Tanta, Kutour & 8 \\
\hline & & E. kobei & Catfish meat, ice cream, cottage cheese & Tanta, Kafr-Elzayat & 8 \\
\hline & & E. ludwigi & Fillet fish & Tanta & 2 \\
\hline \multirow[t]{3}{*}{3} & Citrobacter spp. (12.2\%) & C. Freundii & Fillet fish meat, minced meat, fresh cheese & Tanta & 5 \\
\hline & & C.youngae & Minced meat, yogurt & Tanta, Kafr-Elzayat & 2 \\
\hline & & C.braakii & Minced meat, cottage cheese & Tanta, Kafr-Elzayat & 14 \\
\hline \multirow[t]{3}{*}{4} & Klebsiella spp. (8.7\%) & K.pneumoniae & Yogurt, catfish, milk & Kafr-Elzayat, Tanta, Kutour & 11 \\
\hline & & k. variicola & Yogurt, catfish & Kafr-Elzayat, Tanta & 3 \\
\hline & & k. oxytoca & Milk & Tanta & 1 \\
\hline 5 & Proteus spp. (4.6\%) & P. mirabilis & Milk & Kutour & 8 \\
\hline 6 & Morganella spp. (3.5\%) & M. morganii & Minced meat, milk, fresh cheese & Benha, Kutour, Tanta & 6 \\
\hline 7 & Serratia spp. (1.7\%) & S. marcescens & Minced meat & Benha, Tanta & 3 \\
\hline 8 & Staphylococcus spp. (2.9\%) & S.hominis & Minced meat, cottage cheese, yogurt & Tanta, Kafr-Elzayat & 5 \\
\hline 9 & Pseudomonas spp. (1.1\%) & P. aeruginosa & Milk & Kutour & 2 \\
\hline 10 & Salmonella spp. (0.6\%) & S.Typhimurium & Fillet fish meat & Tanta & 1 \\
\hline 11 & Enterococcus spp. (0.6\%) & E. faecalis & Fresh cheese & Tanat & 1 \\
\hline 12 & Raoultella spp. (0.6\%) & R. planticola & Minced meat & Kafr-Elzayat & 1 \\
\hline 13 & Candida spp. (1.1\%) & Candida krusei & Cottage cheese & Kafr-Elzayat & 2 \\
\hline Total & & 20 & & & 172 \\
\hline
\end{tabular}


obtained from retail markets [22], and broiler chickens and cattle [31]. P. aeruginosa isolates that harbored AMR genes were isolated from $31.57 \%$ of 285 examined fish samples collected from private fish farms [14]. Examination of clinical specimens collected from 133 patients at various hospitals in Cairo revealed presence of K. pneumoniae, P. aeruginosa, E. coli and P. mirabilis in 40.9\%, $17.3 \%, 15.4 \%$ and $2.4 \%$ of samples, respectively [13]. ESKAPE pathogens are the most serious group of bacteria that can 'escape' the biocidal action of antimicrobial agents and are commonly associated with MDR patterns [25]. The presence of such notorious pathogens in fish and milk products constitutes a threat for humans.

Eight Proteus mirabilis strains were isolated from fresh milk in Kutour city. Six Morganella morganii strains were isolated from minced meat, fresh milk and fresh cheese in Benha, Kutour, and Tanta city. P. mirabilis and P. aeruginosa were among the most common infecting organisms causing meningitis in Egypt [32]. Three Serratia marcescens were isolated from minced meat samples obtained from Benha and Tanta. Several outbreaks of S. marcescens infection were reported in neonates in Egypt [3335]. M. morganii, S. marcescens, and P. aeruginosa have been isolated from hospitalized patients in 2014 [36]. Microbes isolated in the current study were collected from the end products prepared for human consumption at points of sale. It is not clear if the contamination source is the animals producing food or humans, or from processing machines and the environment during manufacturing. This study highlights the potential hazard associated with foods in the Delta region of the Nile, which may transmit from food to humans through the food chain.

Several tools were used to monitor foodborne pathogens. LAMP was applied for detecting pathogens in livestock and foodstuffs [37-39], but it is less sensitive and less versatile than PCR, and a proper design of primer is a major challenge [38, 40]. Classical bacteriology is time-consuming, laborious and requires expertise. Although PCR protocols are used broadly, it is limited and identifies only the expected pathogen based on the chosen primers. MALDI-TOF is now widely used for pathogen identification in routine diagnosis [41]. It can identify microorganisms from pure colonies in minutes versus conventional methods based on culture and biochemical assays [42]. MALDI-TOF reliability and accuracy were demonstrated in numerous studies [41, 43, 44], and its use in the control of microbiological hazards in food materials will reduce the cost of consumables and time spent on other conventional diagnostics tools, giving a chance to the rapid choice of an appropriate antimicrobial therapy during food poisoning outbreaks. MALDI-TOF-MS identification is speedy, and only $2 \mathrm{~h}$ are required to examine a full target plate, which is considered an essential factor for food quality and safety, principally during outbreaks of food poisoning that need fast detection. Moreover, the technology requires low reagent costs represent a very substantial benefit in the food safety supply chain [45]. Application of MALDI-TOF was used successfully for microbial identification at the subspecies level in clinical diagnostic laboratories [46] and becomes the first-line diagnostic tool for microorganism identification in the last few years [47]. MALDI-TOF log score values $>2.000$ were accepted in some laboratories for bacterial species identification [48]. However, the score values between 2.300 and 3.000 are considered highly probable species identification [20]. The species misidentification may be compressed the clinical outcome. In clinical laboratories, MALDI-TOF is replacing traditional diagnostic methods because it is a relatively simple technique and can overcome several challenges of identifying bacteria and fungi [49], particularly the databases containing spectra for all known microorganisms are existing.

In conclusion, Foodborne disease outbreaks can produce life-threatening illnesses in humans. To combat the burden of such outbreaks, rapid and accurate pathogen identification is necessary to choose the appropriate antimicrobial therapy rapidly. Zoonotic pathogens associated with food poisoning were determined in food products ready for human consumption at sale points. Presence of ESKAPE pathogens in foodstuffs is alarming and considers threatening public health. Pathogen identification using MALDI-TOF will provide an effective tool to identify the causes of foodborne illness and allow the physicians to apply rapid and effective antimicrobials in an optimized time to the patient.

\section{Limitations}

Limitations are the small number of collected samples and the exclusion of all bacterial agents identified with MALDI score values less than 2.300. Antibiotic susceptibility testing for identified ESKAPE pathogens was required. A further study should be carried out to compare results of MALDT-TOF with other conventional diagnostic techniques (isolation and identification) or molecular methods using PCR.

\section{Abbreviations}

MALDI TOF-MS: Matrix-assisted laser desorption ionization-time of flight mass spectrometry; E.coli: Escherichia coli; E.: Enterobacter; C.: Citrobacter; K.: Klebsiella; P.: Proteus; S.: Staphylococcus; R.: Raoultella.

Acknowledgements

Not applicable. 


\section{Authors' contributions}

Conceptualization, GW, ME and SAM; methodology, GW, DFK and RAL; writing original draft preparation, GW; All authors read and approved the final manuscript.

\section{Funding}

Open Access funding enabled and organized by Projekt DEAL. This research received no external funding.

\section{Availability of data and materials}

Not applicable.

\section{Declarations}

\section{Ethics approval and consent to participate}

Not applicable.

\section{Consent for publication}

Not applicable.

\section{Competing interests}

The authors declare they have no competing interests.

\section{Author details}

${ }^{1}$ Department of Food Hygiene, Animal Health Research Institute, Tanta Laboratory, Tanta, Egypt. ${ }^{2}$ Animal Health Research Institute, Mansoura Provincial Laboratory, Mansoura, Egypt. ${ }^{3}$ Faculty of Veterinary Medicine, Benha University, Moshtohor, Toukh 13736, Egypt. ${ }^{4}$ Friedrich-Loeffler-Institut, Institute of Bacterial Infections and Zoonoses, Jena, Germany.

\section{Received: 11 January 2021 Accepted: 15 March 2021}

Published online: 23 March 2021

\section{References}

1. Stoev SD. Food safety and increasing hazard of mycotoxin occurrence in foods and feeds. Crit Rev Food Sci Nutr. 2013;53(9):887-901.

2. Grace D, Wu F, Havelaar AH. MILK Symposium review: Foodborne diseases from milk and milk products in developing countries-Review of causes and health and economic implications. J Dairy Sci. 2020;103(11):9715-29.

3. Pei X, Li N, Guo Y, Liu X, Yan L, Li Y, Yang S, Hu J, Zhu J, Yang D. Microbiological food safety surveillance in China. Int J Environ Res Public Health. 2015:12(9):10662-70. https://doi.org/10.3390/ijerph120910662.

4. Lawal OU, Fraqueza MJ, Bouchami O, Worning P, Bartels MD, Gonçalves ML, Paixão P, Gonçalves E, Toscano C, Empel J, et al. Foodborne origin and local and global spread of Staphylococcus saprophyticus causing human urinary tract infections. Emerg Infect Dis. 2021;27(3):880-93.

5. Yu CP, Chou YC, Wu DC, Cheng CG, Cheng CA. Surveillance of foodborne diseases in Taiwan: a retrospective study. Medicine. 2021;100(5):e24424.

6. Zhang J, Wang Y, Lu X. Molecular imprinting technology for sensing foodborne pathogenic bacteria. Anal Bioanal Chem. 2021. https://doi.org/10. 1007/s00216-020-03138-x.

7. Hussein MA, Merwad AMA, Elabbasy MT, Suelam IIA, Abdelwahab AM, Taha MA. Prevalence of Enterotoxigenic Staphylococcus aureus and Shiga Toxin Producing Escherichia coli in fish in Egypt: quality parameters and public health hazard. Vect Borne Zoonotic Dis. 2018:19:255-64.

8. Omara S, El Fadaly H, Barakat A. Public health hazard of zoonotic Campylobacter jejuni reference to Egyptian regional and seasonal variations. Res J Microbiol. 2015;10:343-54. https://doi.org/10.3923/jm.2015.3343.3354.

9. Algammal AM, Hetta HF, Elkelish A, Alkhalifah DHH, Hozzein WN, Batiha GE, El Nahhas N, Mabrok MA. Methicillin-Resistant Staphylococcus aureus (MRSA): one health perspective approach to the Bacterium Epidemiology, Virulence Factors, Antibiotic-Resistance, and Zoonotic Impact. Infect Drug Resist. 2020;13:3255-65.

10. Algammal AM, Enany ME, El-Tarabili RM, Ghobashy MOI, Helmy YA Prevalence, antimicrobial resistance profiles, virulence and enterotoxins determinant genes of MRSA isolated from subclinical Bovine Mastitis in Egypt. Pathogens. 2020;9(5):362
11. Abolghait SK, Fathi AG, Youssef FM, Algammal AM. Methicillin-resistant Staphylococcus aureus (MRSA) isolated from chicken meat and giblets often produces staphylococcal enterotoxin B (SEB) in non-refrigerated raw chicken livers. Int J Food Microbiol. 2020;328:108669.

12. Ahmed AM, Shimamoto T. Isolation and molecular characterization of Salmonella enterica, Escherichia coli O157:H7 and Shigella spp. from meat and dairy products in Egypt. Int J Food Microbiol. 2014; 168-169:57-62

13. Makharita RR, El-Kholy I, Hetta HF, Abdelaziz MH, Hagagy Fl, Ahmed AA, Algammal AM. Antibiogram and genetic characterization of Carbapenem-Resistant gram-negative pathogens incriminated in healthcareassociated infections. Infect Drug Resist. 2020;13:3991-4002.

14. Algammal AM, Mabrok M, Sivaramasamy E, Youssef FM, Atwa MH, El-Kholy AW, Hetta HF, Hozzein WN. Emerging MDR-Pseudomonas aeruginosa in fish commonly harbor oprL and toXA virulence genes and bla(TEM), bla(CTX-M), and tetA antibiotic-resistance genes. Sci Rep. 2020;10(1):15961.

15. Saleh FO, Ahmed HA, Khairy RM, Abdelwahab SF. Increased quinolone resistance among typhoid Salmonella isolated from Egyptian patients. J Infect Dev Ctries. 2014:8(5):661-5.

16. Algammal AM, El-Kholy AW, Riad EM, Mohamed HE, Elhaig MM, Yousef SAA, Hozzein WN, Ghobashy MOI. Genes encoding the virulence and the antimicrobial resistance in Enterotoxigenic and Shiga-Toxigenic $E$. coli isolated from Diarrheic Calves. Toxins. 2020;12(6):383.

17. Algammal AM, Mohamed MF, Tawfiek BA, Hozzein WN, El Kazzaz WM, Mabrok M. Molecular typing, antibiogram and PCR-RFLP based detection of Aeromonas hydrophila complex isolated from Oreochromis niloticus. Pathogens. 2020;9(3):238.

18. Enany ME, Algammal AM, Nasef SA, Abo-Eillil SAM, Bin-Jumah M, Taha $A E$, Allam AA. The occurrence of the multidrug resistance (MDR) and the prevalence of virulence genes and QACs resistance genes in $E$. coli isolated from environmental and avian sources. AMB Express. 2019:9(1):192.

19. Huang T, Li L, Liu X, Chen Q, Fang X, Kong J, Draz MS, Cao H. Loop-mediated isothermal amplification technique: principle, development and wide application in food safety. Anal Methods. 2020;12(46):5551-61.

20. Murugaiyan J, Walther B, Stamm I, Abou-Elnaga Y, BrueggemannSchwarze S, Vincze S, Wieler LH, Lubke-Becker A, Semmler T, Roesler $U$. Species differentiation within the Staphylococcus intermedius group using a refined MALDI-TOF MS database. Clin Microbiol Infect. 2014;20(10):1007-15.

21. Ahmed AM, Shimamoto T. Molecular characterization of antimicrobial resistance in Gram-negative bacteria isolated from bovine mastitis in Egypt. Microbiol Immunol. 2011;55(5):318-27.

22. Al-Gamal MS, Ibrahim GA, Sharaf OM, Radwan AA, Dabiza NM, Youssef AM, El-Ssayad MF. The protective potential of selected lactic acid bacteria against the most common contaminants in various types of cheese in Egypt. Heliyon. 2019;5(3):e01362.

23. El-Sharkawy H, Tahoun A, El-Gohary AEA, El-Abasy M, El-Khayat F, Gillespie T, Kitade Y, Hafez HM, Neubauer H, El-Adawy H. Epidemiological, molecular characterization and antibiotic resistance of Salmonella enterica serovars isolated from chicken farms in Egypt. Gut Pathogens. 2017;9:8.

24. Tarabees R, Elsayed MSA, Shawish R, Basiouni S, Shehata AA. Isolation and characterization of Salmonella Enteritidis and Salmonella Typhimurium from chicken meat in Egypt. J Infect Dev Ctries. 2017;11(4):314-9.

25. Santajit S, Indrawattana N. Mechanisms of antimicrobial resistance in ESKAPE pathogens. Biomed Res Int. 2016;2016:2475067.

26. Khalil MAF, Elgaml A, El-Mowafy M. Emergence of multidrug-resistant New Delhi Metallo-beta-Lactamase-1-Producing Klebsiella pneumoniae in Egypt. Microbial Drug Resist. 2017;23(4):480-7.

27. Mohamed ER, Aly SA, Halby HM, Ahmed SH, Zakaria AM, El-Asheer OM. Epidemiological typing of multidrug-resistant Klebsiella pneumoniae, which causes paediatric ventilator-associated pneumonia in Egypt. J Med Microbiol. 2017:66(5):628-34.

28. Hamza E, Dorgham SM, Hamza DA. Carbapenemase-producing Klebsiella pneumoniae in broiler poultry farming in Egypt. J Global Antimicrob Resist. 2016;7:8-10

29. Ishida Y, Ahmed AM, Mahfouz NB, Kimura T, El-Khodery SA, Moawad AA, Shimamoto T. Molecular analysis of antimicrobial resistance in gram-negative bacteria isolated from fish farms in Egypt. J Vet Med Sci. 2010;72(6):727-34 
30. Elhariri M, Hamza D, Elhelw R, Dorgham SM. Extended-spectrum beta-lactamase-producing Pseudomonas aeruginosa in camel in Egypt: potential human hazard. Ann Clin Microbiol Antimicrob. 2017;16(1):21.

31. Tartor YH, El-Naenaeey EY. RT-PCR detection of exotoxin genes expression in multidrug resistant Pseudomonas aeruginosa. Cell Mol Biol. 2016;62(1):56-62.

32. Hammad OM, Hifnawy TM, Omran DA, Zaki S, Daraz A. Gramnegative bacillary meningitis in Egypt. J Egypt Public Health Assoc. 2011;86(1-2):16-20.

33. Ghaith DM, Zafer MM, Ismail DK, Al-Agamy MH, Bohol MFF, Al-Qahtani A, Al-Ahdal MN, Elnagdy SM, Mostafa IY. First reported nosocomial outbreak of Serratia marcescens harboring bla IMP-4 and bla VIM-2 in a neonatal intensive care unit in Cairo Egypt. Infect Drug Resist. 2018;11:2211-7.

34. Elsherbiny NM, Ali IM, Hassanein KM, Ahmed MT. Extended-spectrum beta-lactamase (ESBL)-producing Serratia marcescens causing healthcareassociated infections in Assiut University Hospitals Egypt. J Global Antimicrobial Resist. 2018;13:96-7.

35. Seliem WA, Sultan AM. Etiology of early onset neonatal sepsis in neonatal intensive care unit-Mansoura, Egypt. J Neonatal-Perinatal Med. 2018;11(3):323-30.

36. Khalifa HO, Soliman AM, Ahmed AM, Shimamoto T, Hara T, Ikeda M, Kuroo Y, Kayama S, Sugai M, Shimamoto T. High Carbapenem resistance in clinical gram-negative pathogens isolated in Egypt. Microbial Drug Resist. 2017;23(7):838-44.

37. Liu Z, Zhang Q, Yang NN, Xu MG, Xu JF, Jing ML, Wu WX, Lu YD, Shi F, Chen CF. Rapid and sensitive detection of salmonella in chickens using loopmediated isothermal amplification combined with a lateral flow dipstick. J Microbiol Biotechnol. 2019;29(3):454-64.

38. Sahoo PR, Sethy K, Mohapatra S, Panda D. Loop mediated isothermal amplification: an innovative gene amplification technique for animal diseases. Vet World. 2016;9(5):465-9.

39. Zhuang L, Gong J, Li Q, Zhu C, Yu Y, Dou X, Liu X, Xu B, Wang C. Detection of Salmonella spp. by a loop-mediated isothermal amplification (LAMP) method targeting bcfD gene. Lett Appl Microbiol. 2014;59(6):658-64.

40. Torres C, Vitalis EA, Baker BR, Gardner SN, Torres MW, Dzenitis JM. LAVA: an open-source approach to designing LAMP (loop-mediated isothermal amplification) DNA signatures. BMC Bioinformat. 2011;12:240.
41. Wareth G, Pletz MW, Neubauer H, Murugaiyan J. Proteomics of Brucella: technologies and their applications for basic research and medical microbiology. Microorganisms. 2020;8(5):766.

42. Wieser A, Schneider L, Jung J, Schubert S. MALDI-TOF MS in microbiological diagnostics-identification of microorganisms and beyond (mini review). Appl Microbiol Biotechnol. 2012;93(3):965-74.

43. Sulaiman IM, Hsieh YH, Simpson S. Species identification of Campylobacter jejuni and Campylobacter coli Isolates from raw poultry products by MALDI-TOF MS and rRNA sequence analysis. J AOAC Int. 2020;103(1):197-204

44. Helak I, Daczkowska-Kozon EG, Dłubała AA. Short communication: Enterotoxigenic potential of coagulase-negative staphylococci isolated from bovine milk in Poland. J Dairy Sci. 2020;103(4):3076-81.

45. Elbehiry A, Marzouk E, Hamada M, Al-Dubaib M, Alyamani E, Moussa IM, AlRowaidhan A, Hemeg HA. Application of MALDI-TOF MS fingerprinting as a quick tool for identification and clustering of foodborne pathogens isolated from food products. New Microbiol. 2017;40(4):269-78.

46. Croxatto A, Prod'hom G, Greub G. Applications of MALDI-TOF mass spectrometry in clinical diagnostic microbiology. FEMS Microbiol Rev. 2012;36(2):380-407.

47. Kostrzewa M. Application of the MALDI Biotyper to clinical microbiology: progress and potential. Expert Rev Proteomics. 2018;15(3):193-202.

48. Klotz P, Higgins PG, Schaubmar AR, Failing K, Leidner U, Seifert H, Scheufen S, Semmler T, Ewers C. Seasonal occurrence and Carbapenem Susceptibility of Bovine Acinetobacter baumannii in Germany. Front Microbiol. 2019;10:272.

49. Rychert J. Commentary: benefits and limitations of MALDI-TOF mass spectrometry for the identification of microorganisms. J Infectiology. 2019;2(4):1-5.

\section{Publisher's Note}

Springer Nature remains neutral with regard to jurisdictional claims in published maps and institutional affiliations.
Ready to submit your research? Choose BMC and benefit from:

- fast, convenient online submission

- thorough peer review by experienced researchers in your field

- rapid publication on acceptance

- support for research data, including large and complex data types

- gold Open Access which fosters wider collaboration and increased citations

- maximum visibility for your research: over $100 \mathrm{M}$ website views per year

At BMC, research is always in progress.

Learn more biomedcentral.com/submissions 